\title{
3D Creative Teaching-Learning Strategy in Surveying Engineering Education
}

\author{
Carlos Carbonell-Carrera ${ }^{1 *}$, Jose Luis Saorin ${ }^{1}$, Dámari Melian ${ }^{1}$, Jorge de la Torre Cantero ${ }^{1}$ \\ ${ }^{1}$ University of La Laguna, SPAIN
}

Received 31 May 2017 • Revised 20 September 2017 • Accepted 18 October 2017

\begin{abstract}
For the acquisition of spatial reasoning, content is learned more quickly by means of the use of 3D objects. In the field of surveying engineering education, research has been carried out to promote the ability to interpret relief using $3 D$ terrain representations with positive results, in which the instructor provided these 3D-models to the student. In the present research a change is proposed in the teaching-learning strategy in which the student ceases to be a passive subject who is asked to exercise with a 3D-model to adopt a creative role, since the student creates the object of learning using 3D tools. Under this approach can be measured also the impact of this strategy on creative competence. Results of 2 workshops performed with 115 engineering studies shows that this strategy help them to interpret the relief, and their creativity is improved in 36 points measured with the Abreaction Test of Creativity.
\end{abstract}

Keywords: 3D teaching-learning strategy, 3D digital fabrication, creativity, spatial reasoning (relief interpretation)

\section{INTRODUCTION}

The understanding of topographic relief is necessary for the integration of engineering projects in the environment, and not only in engineering. Disciplines such as architecture, urban planning, and environmental studies among others also make use of the interpretation of relief. In the framework of the European Higher Education Area, a model based not only on the acquisition of competences but on the development of abilities and competences, (BOE, 2007), there are a large number of abilities and learning results related to the representation of relief (Tulla et al., 2004; Chueca et al., 2004): knowledge of the elements of the map and the forms of representation of relief, modelling of the natural environment, knowledge and handling of the precise computer tools for the calculation, cartographical representation of geo-morphological elements, three-dimensional reconstruction and virtual modelling, knowledge of the processes and forms of relief of land towards its integration in the analysis of the landscape and planning (Chueca et al., 2004).

However, in the university context deficiencies have been detected for the interpretation of the relief forms. For the acquisition of these spatial competence, a range of studies have shown that a content is learned more quickly by means of the use of three-dimensional objects (Andrade et al., 2012). In educational areas, objects and models in $3 \mathrm{D}$ are used habitually in different disciplines such as in the teaching of architecture (models) and for technical drawing and standardised views (technical pieces). Álvarez (2011) indicates that the model is a teaching element of the first order.

In the field of surveying engineering, research has been carried out to promote the ability to interpret relief with 3D tools. Thus, several experiments have been carried out in which different learning objects such as augmented reality (Carbonell \& Bermejo, 2017), 3D mesh processing applications and 3D terrain models printed in 3D (Carbonell et al, 2016) have been provided to students. In all these experiments positive spatial reasoning (spatial orientation and relief interpretation) results have been obtained. However, the participants only worked with 3D digital terrain models already built by the instructor: the creation of models is an activity that takes a further step in the process of learning. With this in mind, in the present research the research group for the development of spatial skills at the University of La Laguna conducted a workshop in the course 2015-16 (called 2015-16 Workshop

(C) Authors. Terms and conditions of Creative Commons Attribution 4.0 International (CC BY 4.0) apply. 


\section{Contribution of this paper to the literature}

- A creative approach to the acquisition of spatial competences (interpretation of relief) is presented. Creativity is also a competence to be acquired by engineering students in the European Higher Education Area.

- A 3D creative environment is presented in which 3D low cost technologies are used.

- Results are presented on the interpretation of the terrain in three subscales and on the creative competence in each of its 9 components.

in this paper) in which engineering students also worked with 3D digital terrain models, although in this case the activity consisted of the students to make that 3D terrain model. Thus, a change was proposed in the teachinglearning strategy in which the student ceases to be a passive subject who is asked to exercise with a 3D model to adopt a creative role, since the student creates the object of learning.

It was therefore necessary to evaluate whether this teaching-learning strategy in which the student participates in a creation process had any impact on their creativity competence, since creativity is a generic competence to be acquired by the engineering students in the framework of the European Higher Education Area.

Educational engineering programs do not evaluate academic work in terms of creativity (Daly, Mosyjowski \& Seifert, 2014). Some researchers explain this by arguing that engineering teachers are unfamiliar with teaching and / or creativity assessment (Cropley, 2015; Kazerounian \& Foley, 2007; Zappe, Mena, \& Litzinger, 2013). Although interest in creativity in the engineering field is increasing, little has been done to develop this skill in engineering studies (Cropley \& Crople 1999; Charyton \& Merrill 2009; Dewulf \& Baillie 1999; Kazerounian \& Foley 2007; Stouffer, Russel, \& Oliva, 2004). The importance of creativity in the teaching of engineering is an aspect which is becoming more important, although it is not yet an approach that is fully generalised (Liu \& Schönwetter, 2004). Zappe et al. (2015) claims that students do not perceive that they improved their creative skills in the engineering curriculum, and that they thought that creativity is important in the aim of engineering.

Therefore, another workshop was held by the research group for the development of spatial skills at the University of La Laguna (http:/ / dehaes.webs.ull.es) in the 2016-17 course (called 2016-17 Workshop in this paper) in which engineering students participated in an experiment to create digital terrain models. In this case, since the impact on their interpretation of terrain had already been measured in the 2015-16 Workshop, the influence of this new innovative teaching-learning environment on creative competence was measured.

In this research, therefore, two workshops involving a total of 115 engineering students aimed at to know the impact of a new teaching-learning environment in their spatial reasoning (interpretation of cartographic relief) and to know the improvement of creative competence, by means of the creation of models of the land using technologies of low-cost 3D digital manufacture are described. In the first workshop, carried out during the 2015-16 academic year with 33 university students, topographic models were made using stacked sections, with the aim of improving the three-dimensional interpretation of the terrain forms. The second workshop, performed during the 2016-17 course, was carried out with 82 engineering students. This second experiment aimed to incorporate creative aspects to the generation of land models.

\section{D DIGITAL TERRAIN MODELS IN ENGINEERING}

In professional practice, 3D digital terrain models (DTM) are used as auxiliary tools in making engineering and architectural projects: the model shares with drawing a great expressive synthesis, which makes it an accurate instrument of knowledge which forms part of the basic gearing of the materialisation and physical embodiment of the idea of the project (Carazo \& Galván, 2014). Digital modelling of land and its integration in BIM (Building Information Modeling) environments, facilitate three-dimensional representation. Cazaro and Martínez (2013) state that digital technology is moving graphic production towards a new realism and a new materialism or virtual materialism and they conclude that the world of virtual drawing of the computer has also caused, in parallel, direct connections with the real world through what has been called digital fabrication (Cazaro and Galván, 2014).

In fields of teaching, in turn, the use of topographical 3D terrain models has been common for the understanding of the terrain in a rapid and clear manner (Knoll \& Hechinger, 2005). In Figure 1 a model used at the University of La Laguna for the assimilation of contents related to the levelling and embankment of land is shown. 


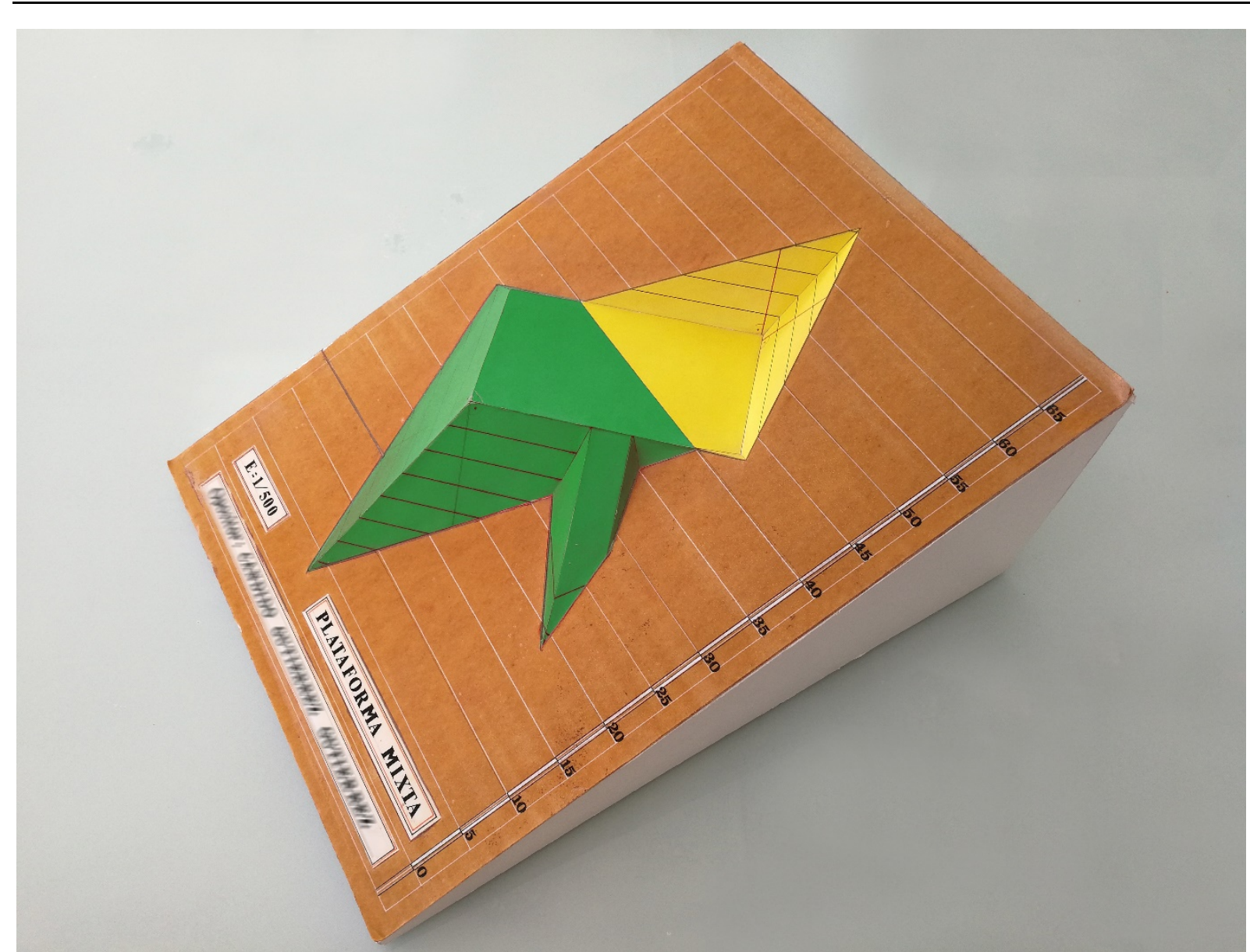

Figure 1. Descriptive model of leveling slopes and embankments by surveyed plans

3D Models are an excellent teaching material in education and for learning to read, interpretation and making of plans which define a project or its different elements, as well as a powerful tool of land-engineering and architectural analysis (Zevi, 1997).

The traditional processes and materials of manufacture (plaster, wood, cork, cardboard and so on) are being replaced by digital modelling of terrain obtained through topographical observations, three-dimensional laser scanning or photogrammetric techniques. A way of simplifying is to use free applications such as SketchUp, which makes it possible to geo-locate a project starting from the data of applications such as Google Earth (Figure 2). This model can be exported in STL format, which is commonly used in digital fabrication processes. 


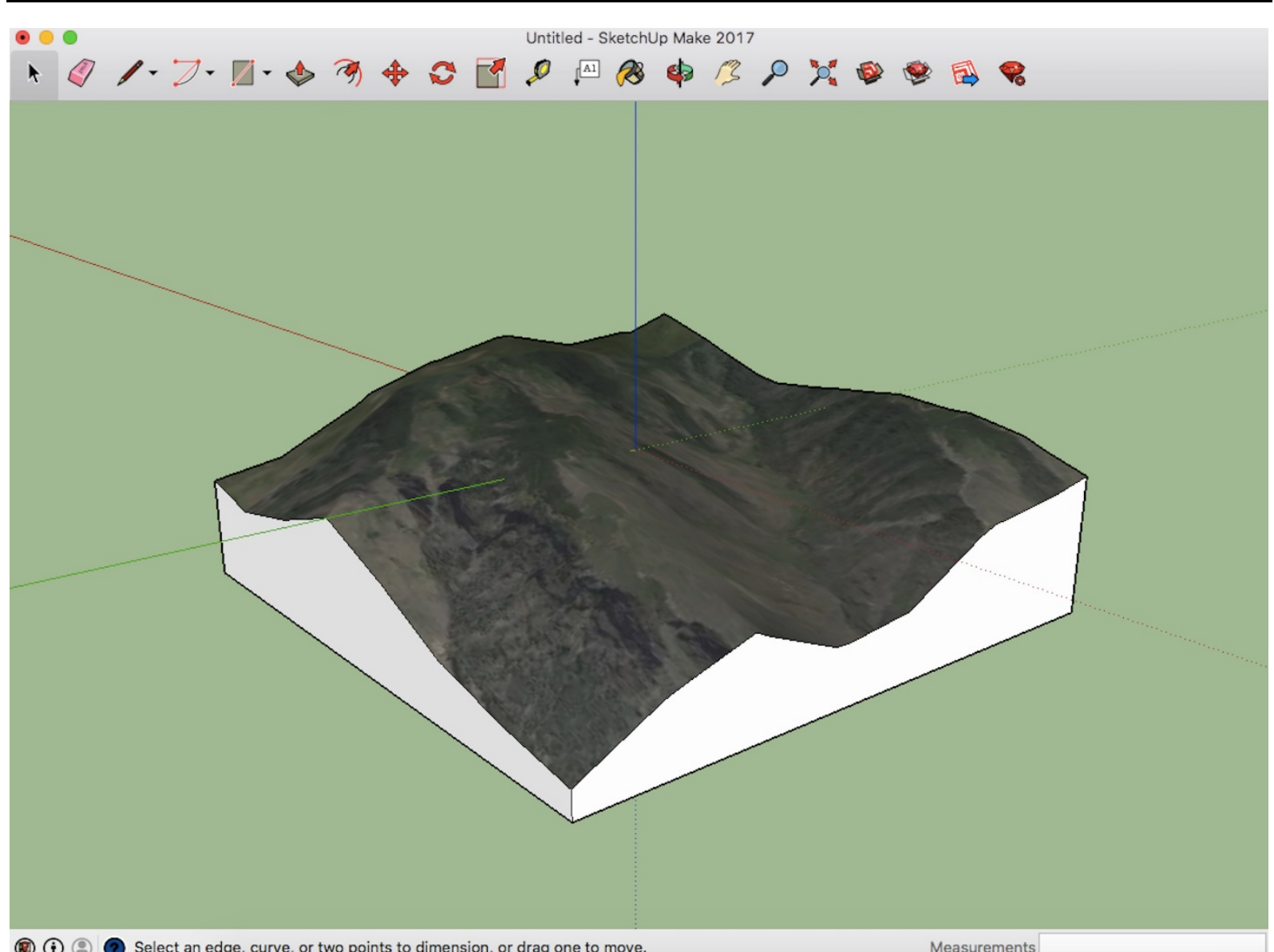

Figure 2. DTM (Digital Terrain Model) in Google SketchUp

New technologies allow the making of models from DTM, through technologies of accessible digital manufacture at low cost. Digital manufacturing technologies are not recent. However, it is in the last few years that they have become considerably cheaper, which makes them accessible in educational contexts. This reduction in cost has arisen both in the hardware and in the software, and the tendency among large software companies such as Autodesk or SketchUp, is to supply some of their applications without charge, such as those used in this research. In the field of hardware, the prices have dropped considerably with the appearance of new companies, which manufacture and distribute devices for digital manufacture.

\section{COMPETENTIAL FRAMEWORK}

The reading and interpretation of topographical maps involves an effort at a cognitive level for the users of cartographical documents, as the information is hierarchically structured and represented through symbols, together with the challenge of interpreting three-dimensional spatial information (cartographic relief) represented in a two-dimensional setting which reproduces topographic relief through different cartographic techniques (Gobert, 2005).

Numerous researchers have studied the difficulties of students in the interpretation of cartographic relief: Boardman (1989) detected problems in the interpretation of contour lines; Carter et al. (2005) concluded that students have difficulties in the transition between 2D representations and their interpretation; Lanca (1998) studied the ability of students to create transverse 3D representations of topographical maps, suggesting the need to go deeper into specific strategies for the understanding of topographical maps.

In educational engineering environments where plans are widely used, the use of 3D digital terrain models aids understanding of three-dimensional space, and can help the acquisition of competences contemplated in Higher Education in engineering such as the interpretation of relief in the framework of spatial reasoning. But not only with the use of 3D digital terrain models already made. Involving the student in the creation of these models can contribute to the improvement of one of the generic competences of the European Higher Education Area: creativity, which is increasingly important in engineering. 
The definition and classification of the competences in the European Higher Education Area are based on the Tuning Project (Project, 2016). This project includes, as a generic competence, the capacity to generate new ideas (creativity) and in Spanish universities the creativity was mentioned in the white paper for Engineering (2014). Furthermore, such institutions as the National Academy of Engineering in the U.S. in its strategic report, "the Engineer of 2020" states that in Humanities and Social Sciences, Communication and Presentation Skills are more, or at least equal in importance to technical knowledge for a professional engineer. Precisely, in this report in particular, it is said that "it is appropriate that engineers should be educated to understand and appreciate history, philosophy, culture and the arts together with the creative elements of all these disciplines".

In the engineering profession, it is often necessary to bring different solutions to the same problem, in a creative and novel way. A creative mind will be able to solve tasks related to the design of a product or the improvement of an existing one. Creativity is defined as the generation of ideas in a novel and useful (or appropriate) way (Sternberg \& Lubart, 1995; Sternberg, 1999; Weisberg, 1986). Some authors call this definition "general creativity" (Charyton, 2005; Charyton \& Snelbecker, 2007). In a stricter sense, it is understood as "creativity in engineering", a way of thinking that contributes to new and original ideas, and that reaches high levels of usefulness in a functional and practical way that is easy to apply (Charyton, Jagacinski, \& Merrill, 2008; Charyton \& Merrill, 2009). There is, therefore, a great link between engineering and creativity, to the point that some authors think that if engineers are not creative, they are not engineers (Elliot, 2001).

It is necessary, therefore, to incorporate and stimulate creativity in the training of engineers, through activities, strategies and teaching methodologies that can develop this skill, to respond to a society that demands creative skills profiles to meet the challenges of a constantly changing world (Saorín et al., 2015; Saorín et al., 2017). Scott et al., (2004) concluded that training programs that included activities focused on creativity were successful.

Creative competence in engineering can be enhanced with training (Scott et al., 2004; Cropley \& Cropley, 2000). In turn, spatial reasoning (in terms of interpretation of relief) can also be developed with specific training (Carbonell et al., 2016). The present research brings the results of an innovative teaching / learning environment focused on the development of these two competences.

\section{Creativity Measurement}

The four most-used measuring instruments in the country where the research has been carried out (Spain), where the features that are evaluated in each instrument are mentioned, together with the factors that are studied, and their adaptation or otherwise for the object of analysis which concerns us are. The first one is the Guilford creativity battery. This instrument assesses the features of fluidity, flexibility, originality, elaboration and sensitivity. It analyses the fundamental factors corresponding to divergent thinking, as this is what is usually interpreted as corresponding to creativity. The second one is the Torrance Creative Thinking Tests. The features which are assessed in these tests are those of fluidity, flexibility, originality, elaboration, inventiveness and penetration. They study a general creative capacity, search for models of the creative process in their natural development, which in turn confer upon tests a capacity for methodological handling which is more accessible and reliability of the results. The third one is the Corbalán CREA test. This tool can be applied with individuals of six years of age onwards, both male and female, and is useful in clinical, educational and organisational contexts and in the practice of the arts, design and advertising. Unlike the Guilford battery, which takes into account the five above-mentioned factors, the CREA test proposes a single measurement of creativity, as it is studied as a psychological style. Thus, the CREA uses as a procedure for measuring creativity the capacity of the individual to ask questions, which serve as an indicator. Finally, the last one is the Abreaction Test for Evaluation of Creativity (TAEC - abbreviation of the Spanish name) from de la Torre (1991). This test can be applied from pre-school to adulthood and is a graphic-inductive test of completion of figures, and it is for this reason that this test has been selected to carry out this experiment.

This test has been chosen among all the existing ones due to the fact that it is a graphic-inductive test of completion of figures, which is highly suitable for use in the context of the subject of Graphic Expression in degrees of Engineering.

The test can be applied to pupils of different ages, from pre-school up to adulthood as it has two variables according to the age of the user. It does not have specific instructions and can be used by any teacher without prior knowledge of the subject. It does not give difficulties either in the conduct by the subject, and it therefore gives full liberty in the way it is used.

As regards its structure, the test is made up of twelve figures with a total of thirty-six openings, in a diversity of positions and shapes. Once the pupil makes his/her drawings or global composition, the features of resistance to closure, originality, elaboration, fantasy, connectivity (creative integration), imaginative scope, figurative expansion, expressive richness, graphic ability, morphology of the image and creative style, through the graphic stimulus are assessed, as described below: 
Abreaction or resistance to closure: it is the control that the person has not to close the openings that the test presents without being carried away by the natural tendency for it to be closed. It can be manifested in two ways, leaving the opening open or closing it by an indirect path (by more than two strokes, away from the closing points or using original closures). When correcting the test, it is valued with one point each of the openings that are open or partially open.

Originality: measures the ability to make different responses to the rest of the group (unusual and unconventional responses). This factor is one of those that already appears in the first tests of creativity given to pre-schoolers by E.A. Kirkpatrick (1907) and with university students in 1916 through the Test for originality of L.M. Chassell (1916). It can be said that Originality is the component with the greatest importance to diagnose the creative component of subjects. Originality is evaluated on a scale of 0 to 3 depending on the frequency with which that drawing is repeated within the set.

Elaboration: the level of detail added to the drawings (e.g. an emoticon type face is understood, but you can make a face with many more details). This factor also appears in the tests of Guildford and Torrance. To elaborate is to treat something in detail, carefully and meticulously. This factor is evaluated from 0 to 3 depending on the number of additional details that the subject uses in the development of the response.

Fantasy: it is the representation of something, which is non-existent, in which elements of past experience are combined with new aspects. This variable is not measured in other creativity tests. People with little imagination will imagine objects from a familiar environment, while individuals with this value most accentuated draw from the figures objects that do not exist in real life. It evaluates from 0 to 3 , depending on the degree of realism that the drawing presents. If for example, it is a known object, it will have a lower score than if it is a drawing of a nonexistent object.

Connectivity (creative integration): it measures the fact that a drawing connects several of the 12 figures that compose the test. The tendency in this test is to make a single composition with each of the figures; very few use several of the figures for the realization of a composition. This factor is valued according to whether some figures are connected to others for the creation of the same composition, granting 3 points for each figure that is connected to another.

Imaginative scope: the starting figure is camouflaged as a secondary element within the drawing enhanced by the subject. If the figure is a main element of the composition, the person will have less imaginative scope than if instead it becomes an unnoticed element within the composition. The values are from 0 to 3 , where 0 is for a composition in which the figure is used as the main object, while it will have an increasingly high score as soon as the figure goes unnoticed inside the composition.

Figurative expansion: It measures the space occupied by the drawing. It is measured with a template where each figure is bordered with a template of given dimensions. This factor responds to an attitude or tendency of the person to face risks and to exceed the limits given. To evaluate this factor, a template is needed that establishes the score from 0 to 3 , based on the extension that the composition exceeds.

Expressive richness: It measures whether the drawing represents static objects or whether moving objects are represented. The values are from 0 to 3 , the minimum score being given to subjects that represent static objects without perspective or colour, and the score increasing for subjects if they represent moving objects, and if, in addition to this, they use colour in their compositions.

Graphic skill: the following elements of the drawing are valued: coordinated movements, firmness in the stroke, sureness of movements, speed and precision, proportion in the parts of the picture, and mastery of certain techniques such as perspective and shading. This factor is evaluated from 0 to 3 , depending on the graphic security that the subject has in their compositions.

\section{METHODOLOGY}

In the present research, the results of two field experiments carried out with engineering students at the University of La Laguna are presented. The first of them (2015-16 Workshop) took place during the 2015-2016 academic year aimed at the interpretation of terrain by means of the use of models created with low-cost digital fabrication tools. The second experiment (2016-17 Workshop), carried out during the 2016-2017 academic year, measured whether the creation of 3D terrain models in experiment one is a valid strategy to improve the creative competence of engineering students. Therefore, two hypotheses are posed: with the 2015-16 workshop, to check if it improves the student's ability to interpret the students' profile, and with the 2016-17 workshop to check if the creation of 3D DTM increases their creative competence. 


\section{5-16 Workshop}

\section{Participants}

Thirty-three students of engineering at the University of La Laguna of the 2015-2016 academic course separated into eleven groups of three members each participated in the 2015-16 Workshop aimed to improve their relief interpretation.

\section{Procedure}

The 2015-16 workshop was held in three hours, within the schedule of practical classes.

Session 1 (1 hour): Five paper maps were supplied, on which the relief of the land was represented via different 2D cartographic techniques: contour lines, orthophotos, hypsometric tints combined with contour lines, colour scales and oblique zenith shading with hypsometric tints combined with contour lines. Each kind of representation contains a series of questions about the interpretation of the land which the students must identify on the map: routes, lines of maximum slope, elevations, hills, dividing lines, watercourses, vertices and depressions.

Session 2 (2 hours): From the five maps in Session 1, the students are given the terrain represented in a digital $3 \mathrm{D}$ format (STL) and the construction of the model is carried out. With the 123D Make programme (now known as Slicer for Fusion), the students have to build a model of $15 \times 15 \mathrm{~cm}$ using the so-called Stacked Slices manufacturing technique. Using this technique, the programme generates horizontal sections of land similar to the contour lines. The thickness of each section (according to the material used) and the shape of the land, will determine the number of parts of which the model will be made up (Figure 3).

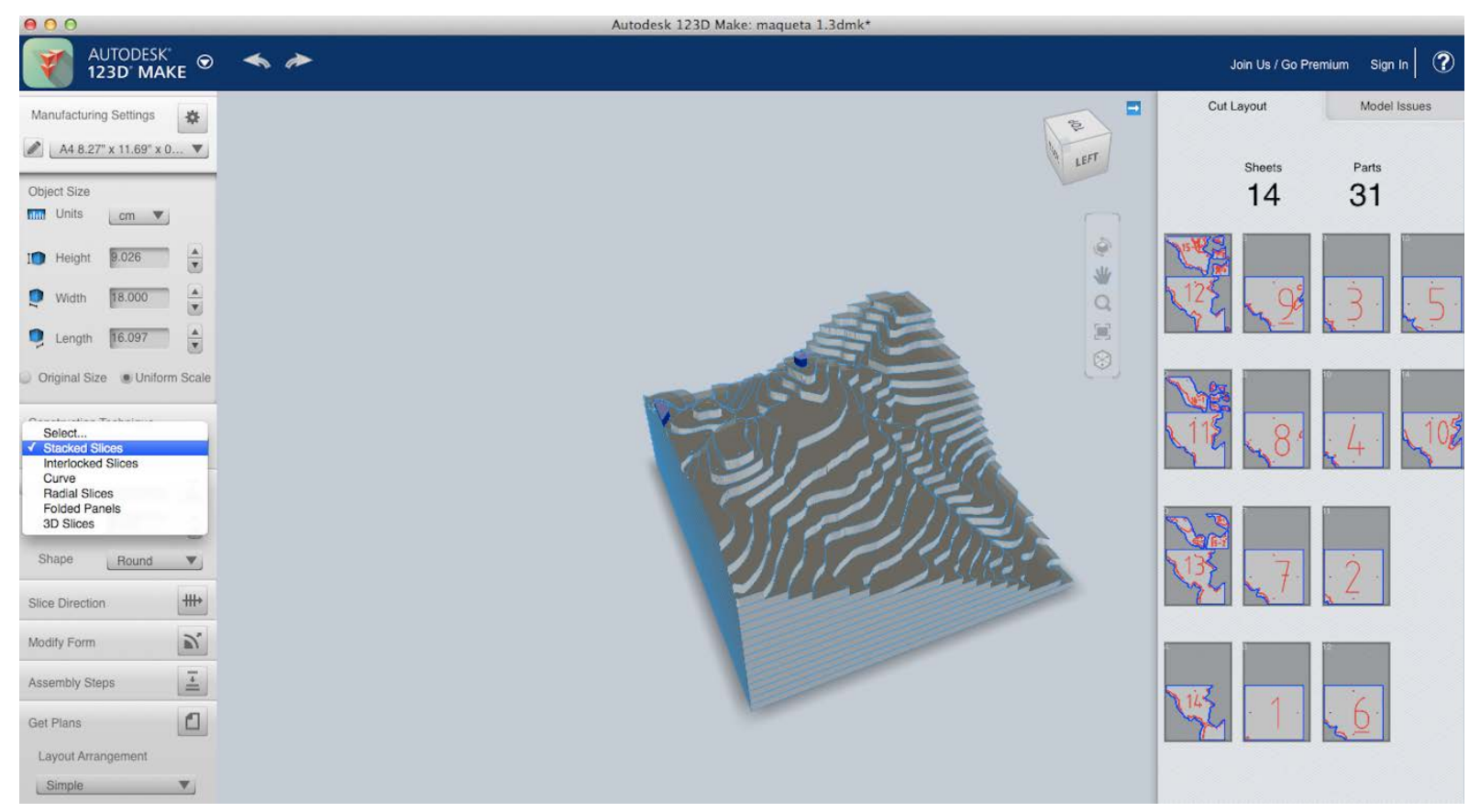

Figure 3. Autodesk 123 Make screen capture 
Once the templates of the paper sections are printed, they are stuck onto ethylene vinyl acetate to be cut out and to proceed to stick the layers in the correct order (Figure 4). This material, also known as EVA rubber, is cheap and easy to cut with a cutter and/or scissors. Each piece is numbered and if the assembly of the land were to present any kind of difficulty, it is possible to have recourse to the assembly video offered by the programme.
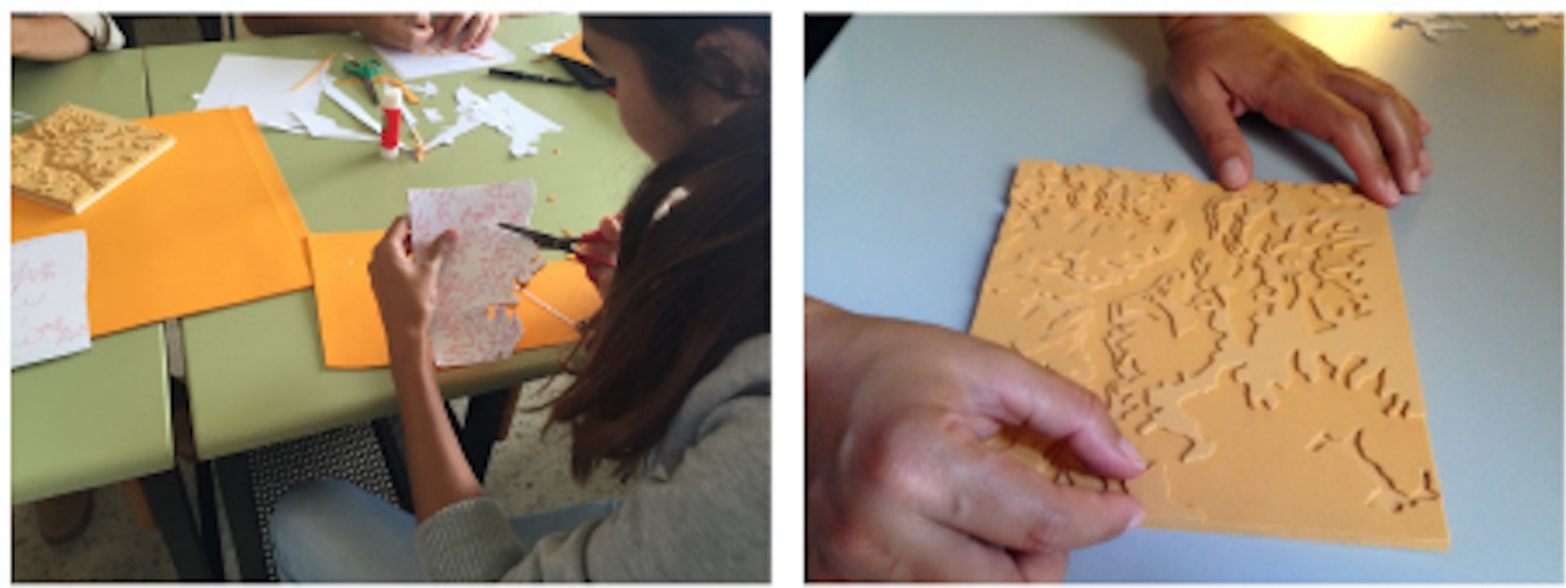

Figure 4. Cutting out the sections of ethylene vinyl acetate and the creation of the model

Once the model is finished, the students verify the answers given to the questions about the interpretation of the relief asked in Session 1 with the 2D representation, comparing whether their understanding of the space expressed through a map corresponds with their three-dimensional view. The following image (Figure 5) shows a type of 2D representation (contour lines and the corresponding model).

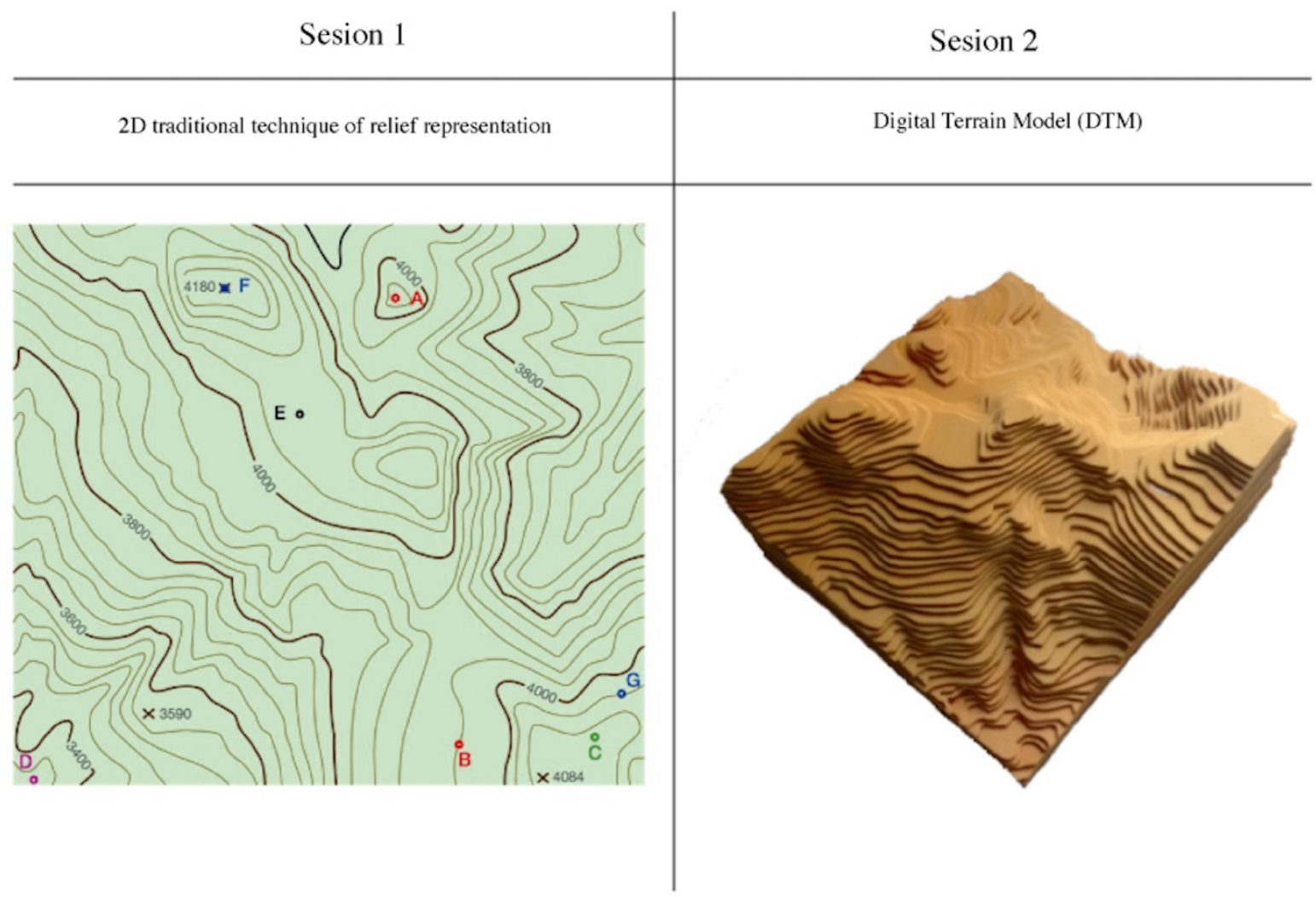

Figure 5. Representations in 2D with traditional cartographic techniques and the version as a model 
At the end of the workshop, the participants were given a relief interpretation survey (Table 1).

\section{6-17 Workshop}

\section{Participants}

The activity took place in the 2016-17 course with eighty-two students of engineering at the University of La Laguna separated into two groups: the treatment group, made up of fifty-seven students and the control group made up of twenty-five students.

Both groups had the creativity measurement carried out at the beginning and at the end of the experiment, although only the treatment group carried out the workshop on the creation of models with low-cost digital manufacturing technologies.

\section{Procedure}

For this activity, two sessions were used, the first of one hour and the second of four hours.

Session 1 (1 hour): The students, both the treatment group and the control group, did the TAEC creativity test (Pre-test) so as to have an initial valuation of the creativity of the group.

Session 2 (4 hours): In this session, the treatment group did the model-making workshop while the control group did not participate in this phase of the workshop. For the workshop done by the treatment group, the students were divided into sub-groups of four or five participants. Each sub-group of students had to select the place with which they would subsequently work to make the model of the terrain. The students located the land that had been indicated to them and determined the sizes and scales that the model of the land would have. All of this was done with the free SketchUp programme (2016 version).

As an additional task, these students were asked to make a platform on the land and to construct the volume of a building, which would go on that platform. Therefore, each sub-group generated two files in STL format, one of the land and another of the building. The STL file of the building of each sub-group was printed directly on a 3D printer. 3D printers are machines that, working from digital files, make it possible to generate objects by the addition of materials (molten plastic, photo-sensitive resin, etc.). This technology is also known as rapid prototype (Canessa, Fonda \& Zennaro, 2013). There are currently several brands such as Cube, BQ or Makerbot among others, which offer devices at low cost that are easy to use. Specifically, the 3D printer used in this workshop was the Makerbot Replicator 2.

For the construction of the model of the land, the 123D Make programme was used. The participants had to construct a model in the same way that it was built in Session 2 of 2015-16 workshop.

Making the right selection is important for any subsequent work on the model of the objet, as well as choosing the right manufacturing method, materials and scale. For example, very steep ground will inevitably play a crucial role in the design of the building to be constructed on it; accordingly, the scale model should also represent and be made taking such terrain into account (Stavric et al, 2013). Thus, in the research carried out in this paper, the experiments aimed to incorporate creative aspects to the generation of land models in the sense that the participants adopt different solutions around the resolution of a proposal (definition of the concept of creativity): the height of the esplanade where the building is to be located, the orientation of this esplanade, the location of the building within the selected area, the choice of the inclination of the slopes, the $3 \mathrm{D}$ digital scale modelling as well as the scale of deformation of the $\mathrm{Z}$ axis to obtain an optimal representation.

Once the students in the treatment group had finished their models, they did the TAEC creativity test again together with the control group (Post Test).

\section{RESULTS}

\section{Results of the 2015-16 Workshop}

At the end of the first workshop, the participants were given a relief interpretation survey (Table 1) with responses on the Likert scale ( 1 totally disagree, 5 totally agree). In this survey, the first three questions (Q1, Q2, Q3) referred to the improvement in the comprehension of relief, the following three questions (Q4, Q5, Q6) referred to basic concepts associated with three-dimensional interpretation of the land and questions Q7 and Q8 made reference to the 123D Make tool used for the creation of the model. An estimate of the reliability of the questionnaire was calculated using Cronbach's alpha, obtaining a value of 0.78 . Cronbach's alpha coefficient could be: $>0.9$ excellent; >0.8 good; 0.7 acceptable; 0.6 questionable and >0.5 poor (George \& Mallery, 2003). 
Table 1. Relief interpretation survey

Relief interpretation survey

\begin{tabular}{|c|c|c|c|}
\hline Question & & & $\begin{array}{l}\text { Average } \\
\text { (s.d.) }\end{array}$ \\
\hline \multirow{3}{*}{$\begin{array}{l}\text { Improvement of } \\
\text { comprehension of } \\
\text { relief }\end{array}$} & Q1 & $\begin{array}{l}\text { The process of making the 3D digital terrain models allowed me to visualize the } \\
\text { geographical accidents necessary, improving my understanding of relief. }\end{array}$ & $\begin{array}{c}4.2 \\
(0.56)\end{array}$ \\
\hline & Q2 & $\begin{array}{l}\text { 3D digital terrain models are useful for learning the basic concepts of cartography } \\
\text { and topography. }\end{array}$ & $\begin{array}{c}4.34 \\
(0.70)\end{array}$ \\
\hline & Q3 & $\begin{array}{l}\text { With the 3D terrain model I interpret the shapes of the relief better than with the } \\
2 \mathrm{D} \text { representation. }\end{array}$ & $\begin{array}{c}4.34 \\
(0.60) \\
\end{array}$ \\
\hline \multirow{3}{*}{$\begin{array}{l}\text { Basic concepts } \\
\text { associated with } \\
\text { three-dimensional } \\
\text { interpretation of } \\
\text { the land }\end{array}$} & Q4 & $\begin{array}{l}\text { With the 3D terrain model I understand the concept of the contour line better than } \\
\text { with the } 2 \mathrm{D} \text { representation. }\end{array}$ & $\begin{array}{c}4.38 \\
(0.79)\end{array}$ \\
\hline & Q5 & $\begin{array}{l}\text { With the 3D terrain model I understand the concept of the maximum slope line } \\
\text { better than with the 2D representation. }\end{array}$ & $\begin{array}{c}4.13 \\
(0.79)\end{array}$ \\
\hline & Q6 & $\begin{array}{l}\text { With the } 3 \mathrm{D} \text { terrain model I understand the concepts of the longitudinal and } \\
\text { transverse profiles better than with the } 2 \mathrm{D} \text { representation. }\end{array}$ & $\begin{array}{c}3.84 \\
(1.05) \\
\end{array}$ \\
\hline \multirow{2}{*}{ 123D Make tool } & Q7 & $123 \mathrm{D}$ Make is a good tool for making models of land in 3D. & $\begin{array}{c}4.4 \\
(0.51)\end{array}$ \\
\hline & Q8 & $\begin{array}{l}\text { The use of 123D Make to introduce 3D modelling of land in the classroom seems } \\
\text { very interesting to me. }\end{array}$ & $\begin{array}{c}4.1 \\
(0.60)\end{array}$ \\
\hline
\end{tabular}

s.d. standard deviation

\section{Results of the 2016-17 Workshop}

The Abreaction Test for Evaluating Creativity scores ranges from 0 to 324 points, since each of the 12 figures can receive a quantitative score of 0 to 3 points for each of the nine variables analysed. That is to say that a student can obtain from 0 to 36 points in each component. Table 2 shows the creativity results for the treatment group.

Table 2. Treatment Group Abreaction Test for Evaluating Creativity

\begin{tabular}{|c|c|c|c|}
\hline & $\begin{array}{c}\text { Pre-test } \\
\text { Mean Score } \\
\text { (s.d.) }\end{array}$ & $\begin{array}{c}\text { Post-test } \\
\text { Mean Score } \\
\text { (s.d.) }\end{array}$ & $p$-value \\
\hline $\begin{array}{c}\text { Creativity } \\
\text { Test Score } \\
\text { Range: } 0 \text { to } 324\end{array}$ & $\begin{array}{c}84.0 \\
(42.58)\end{array}$ & $\begin{array}{c}122.0 \\
(43.64)\end{array}$ & 0.0000 \\
\hline \multicolumn{4}{|l|}{$\begin{array}{c}\text { Creativity Components } \\
\text { Range: } 0 \text { to } 36\end{array}$} \\
\hline Abreaction & $\begin{array}{l}12.86 \\
(6.13) \\
\end{array}$ & $\begin{array}{l}14.61 \\
(5.19) \\
\end{array}$ & 0.0141 \\
\hline Originality & $\begin{array}{l}10.80 \\
(5.97)\end{array}$ & $\begin{array}{l}15.38 \\
(5.63)\end{array}$ & 0.0000 \\
\hline Elaboration & $\begin{array}{r}6.50 \\
(7.04) \\
\end{array}$ & $\begin{array}{l}10.94 \\
(5.81) \\
\end{array}$ & 0.0000 \\
\hline Fantasy & $\begin{array}{c}4.85 \\
(5.37) \\
\end{array}$ & $\begin{array}{c}9.10 \\
(7.27) \\
\end{array}$ & 0.0000 \\
\hline Connectivity & $\begin{array}{l}4.31 \\
(9.99)\end{array}$ & $\begin{array}{c}7.90 \\
(11.91)\end{array}$ & 0.0021 \\
\hline Imaginative scope & $\begin{array}{l}11.23 \\
(4.45) \\
\end{array}$ & $\begin{array}{l}20.62 \\
(8.32) \\
\end{array}$ & 0.0000 \\
\hline Figurative expansion & $\begin{array}{l}18.15 \\
(9.59) \\
\end{array}$ & $\begin{array}{l}26.5 \\
(8.41)\end{array}$ & 0.0000 \\
\hline Expressive richness & $\begin{array}{r}6.87 \\
(3.89) \\
\end{array}$ & $\begin{array}{c}8.45 \\
(5.16) \\
\end{array}$ & 0.0158 \\
\hline Graphic skill & $\begin{array}{c}8.36 \\
(6.29) \\
\end{array}$ & $\begin{array}{c}8.55 \\
(6.31) \\
\end{array}$ & 0.8632 \\
\hline
\end{tabular}

s.d. standard deviation

Figure 6 shows the results for the creativity components of the treatment group. It shows graphically the increase in each one of the components of creativity. Imaginative Scope and Figurative Expansion are those that have experimented a greater improvement after the realization of the workshop. 




Figure 6. Graph of results by component in the treatment group

To verify that the control group had the same creativity characteristics as the treatment group, a Student $t$ of the values of the Abreaction Test for Evaluating Creativity (pre-test) was performed before the workshop. The difference between these values ( 84.0 for the treatment group and 85.6 for the control group) was not significant ( $p$ level=0.85), so it can be said that both groups have similar values for creativity. Table 3 shows the creativity results for the control group.

Table 3. Control Group Abreaction Test for Evaluating Creativity

\begin{tabular}{|c|c|c|c|}
\hline & $\begin{array}{c}\text { Pre-test } \\
\text { Mean Score } \\
\text { (s.d.) }\end{array}$ & $\begin{array}{c}\text { Post-test } \\
\text { Mean Score } \\
\text { (s.d.) } \\
\end{array}$ & $p$-value \\
\hline $\begin{array}{c}\text { Creativity } \\
\text { Test Score } \\
\text { Range: } 0 \text { to } 324\end{array}$ & $\begin{array}{c}85.6 \\
(37.49)\end{array}$ & $\begin{array}{c}96.2 \\
(47.76)\end{array}$ & 0.4766 \\
\hline \multicolumn{4}{|l|}{$\begin{array}{c}\text { Creativity Components } \\
\text { Range: } 0 \text { to } 36\end{array}$} \\
\hline Abreaction & $\begin{array}{l}13.83 \\
(5.42) \\
\end{array}$ & $\begin{array}{l}10.75 \\
(5.19) \\
\end{array}$ & 0,1250 \\
\hline Originality & $\begin{array}{l}12.96 \\
(5.43) \\
\end{array}$ & $\begin{array}{l}13.56 \\
(5.83) \\
\end{array}$ & 0,762 \\
\hline Elaboration & $\begin{array}{r}9.26 \\
(6.62) \\
\end{array}$ & $\begin{array}{l}11.86 \\
(8.64) \\
\end{array}$ & 0,3202 \\
\hline Fantasy & $\begin{array}{r}3.18 \\
(2.98) \\
\end{array}$ & $\begin{array}{c}3.10 \\
(2.73) \\
\end{array}$ & 0,941 \\
\hline Connectivity & $\begin{array}{c}5.17 \\
(9.47) \\
\end{array}$ & $\begin{array}{c}7.78 \\
(12.13) \\
\end{array}$ & 0,4784 \\
\hline Imaginative scope & $\begin{array}{l}11.03 \\
(6.16) \\
\end{array}$ & $\begin{array}{l}13.22 \\
(9.88) \\
\end{array}$ & 0,4139 \\
\hline Figurative expansion & $\begin{array}{l}22.05 \\
(9.04)\end{array}$ & $\begin{array}{l}22.35 \\
(8.88)\end{array}$ & 0,9244 \\
\hline Expressive richness & $\begin{array}{r}5.66 \\
(3.76) \\
\end{array}$ & $\begin{array}{r}6.64 \\
(6.67) \\
\end{array}$ & 0,5684 \\
\hline Graphic skill & $\begin{array}{r}2.48 \\
(5.06) \\
\end{array}$ & $\begin{array}{c}6.87 \\
(6.10) \\
\end{array}$ & 0,0268 \\
\hline
\end{tabular}

s.d. standard deviation 


\section{DISCUSSION AND CONCLUSIONS}

In accordance with the results of the first experiment, we can conclude that:

Students perceive that this new teaching-learning environment as an innovate educational strategy that helps them to interpret the relief (all questions raised offer values above 3.84 out of 5 ).

The use of models improves the understanding of relief (Q1, Q2, Q3): the valuation by the students of these three questions is high (values greater than 4 out of 5). In this regard, not only the use of models but also the process of making the models helps towards a greater understanding of the shape of the land.

Basic concepts associated with the three-dimensional interpretation of the land $(\mathrm{Q} 4, \mathrm{Q} 5, \mathrm{Q} 6)$ such as the contour lines, line of maximum slope and longitudinal and/or transverse sections are better acquired using models (the scores of the three questions are over 3.8 out of 5) than with traditional representation of land on maps and plans.

Free tools such as 123D Make (now known as Slicer) are well considered (Q7, Q8) by the students for making models (scores higher than 4 out of 5). Likewise, they consider this new 3D learning environment as very interesting.

In respect to creativity competence, from the analysis of the results of the present research, we can conclude that:

The terrain model creation workshop improves the creative competence of engineering students. In the treatment group, there is a statistically significant difference ( $p$-value $<0.01)$ between the pre-test $(84.0)$ and the posttest (122.0) of 36.00 points in the Creativity Test Score. Students exercise their creativity by adopting different solutions around the same problem, in order to adopt the most effective and purposeful fabrication and representation procedure.

Analysing the results of the components of creativity, all the components show a statistically significant improvement except for the component of graphic skill ( $p$-value $=0.8632$ ). After the workshop, the participants increase in the components of imaginative scope by 9.39 points and figurative expansion by 8.35 points. They are more original (gain $=4.58$ ), and are capable of supplying novel solutions to a specific problem. Originality, as mentioned above, is the most important component of creative competence. In turn, they have a greater capacity for detail and thoroughness (elaboration component: gain $=4.44$ ), so necessary in engineering and the tendency to composition of different parts is increased (connectivity: gain $=3.59$ ). In engineering, the parts or components are the individual elements of a set or sets; it is a concept which is very much present in CAD software. Finally, other components that present an increase are fantasy (gain $=4.25$ points) and connectivity (gain $=3.59$ points).

It can be said, therefore, that there is an overall improvement in creativity and not only in some of the components of creativity.

The results of the control group in the test of creativity score confirm that those students who did not participate in the creation of land models workshop did not improve in creative competence or in any of the components. This coincides with the experiments cited below, in which students worked in a project-based learning environment and using 3D printers.

The realization of the workshop allows improvements in creativity competence comparable to other experiments carried out with engineers. In order to contextualize the results for creativity in the 2016-17 workshop, there is other research that has measured the improvement of creativity of engineering students using the same test. In 2011, at the University of Valencia, research on creativity was carried out with a group of students of Industrial Design (Lifante Gil, 2011). 15 students had their creativity measured before and after performing a project based learning (PBL) activity. The results of the Creativity Post-Test Score were 112.7 with an improvement of 27.3 points. Also, in the University of La Laguna, an activity was carried out (Saorín et al., 2017) with 44 first year engineering students, in which the participants worked with applications of design and edition of meshes and 3D printers. Participants scored 139.2 in the Creativity Test Score post-test. In both studies, in which a control group was also considered, it was found that students who did not receive specific training did not increase their creativity competence.

\section{ACKNOWLEDGEMENTS}

The research carried out is within the framework of the actions with the Spanish Ministry of Education, Culture and Sport, within the framework of the State Program for the Promotion of Talent and its Employability in I+D+i, State Mobility Subprogram of the State Plan for Scientific and Technical Research and Innovation 2013-2016.

This work has been supported by the University of La Laguna: Innovative Educational Project for the academic year 2017/ 2018 called “3D environments for terrain modelling”. 


\section{REFERENCES}

Agencia Nacional de Evaluación de la Calidad y Acreditación. (2004). Libros Blancos.

Álvarez Prozorovich, F. V. (2011). Rastrear proyectos, contar historias. Diagonal, (2011), 10-13.

Andrade-Lotero, L. A., Espitia-Gómez, C., Huertas-Franco, E. A., Aldana-Ahumada, D. R., \& Bacca-Pachón, P. A. (2012). Tocar o mirar: comparación de procesos cognitivos en el aprendizaje con o sin manipulación física. Revista de Psicología Educativa, 18(1), 29-40.

Boardman, D. (1989). The development of graphicacy: Children's understanding of maps. Geography, 321-3.

Canessa, E., Fonda, C., \& Zennaro, M. (2013). Low-cost 3D printing: for science, education E sustainable development. ICTP - The Abdus Salam International Centre for Theoretical Physics.

Carazo E., \& Galván N., (2014). EGA. Revista de expresión gráfica arquitectónica. Aprendiendo con maquetas. Pequeñas maquetas para el análisis de arquitectura, (24), 62-71.

Carazo, E., Martínez, S. (2013). La generación digital. Más notas para el debate sobre una cibernética de la arquitectura. EGA. Revista de expresión gráfica arquitectónica, 18(22), 50-59.

Carbonell Carrera, C., \& Bermejo Asensio, L. A. (2017). Augmented reality as a digital teaching environment to develop spatial thinking. Cartography and geographic information science, 44(3), 259-270.

Carbonell Carrera, C., Avarvarei, B. V., Chelariu, E. L., Draghia, L., \& Avarvarei, S. C. (2016). Map-Reading Skill Development with 3D Technologies. Journal of Geography, 116(5), 197-205.

Carter, G., Patrick, M., Wiebe, E. N., Park, J. C., \& Butler, S. M. (2005). Middle grade students' interpretation of topographic maps. Paper presented at the National Association for Research in Science Teaching NARST.

Charyton, C. (2005). Creativity (scientific, artistic, general) and risk tolerance among engineering and music students (Doctoral dissertation, ProQuest Information \& Learning).

Charyton, C., \& Merrill, J. A. (2009). Assessing general creativity and creative engineering design in first year engineering students. Journal of engineering education, 98(2), 145-156.

Charyton, C., \& Snelbecker, G. E. (2007). General, artistic and scientific creativity attributes of engineering and music students. Creativity Research Journal, 19(2-3), 213-225.

Charyton, C., Jagacinski, R. J., \& Merrill, J.A. (2008). CEDA: A research instrument for creative engineering design assessment. Psychology of Aesthetics, Creativity, and the Arts, 2(3), 147-54.

Chassell, L. M. (1916). Tests for originality. Journal of educational psychology, 7(6), 317.

Chueca, M., Salcedo, F., Ferrer, J., Galán, L., \& Olivé, J. (2004). White paper title engineer degree in geomatics and surveying. National Agency for Quality Assessment and Accreditation (ANECA) Spain, 118-148.

Cropley, D. H. (2015). Promoting creativity and innovation in engineering education. Psychology of Aesthetics, Creativity, and the Arts, 9(2), 161-171. doi:10.1037/aca0000008

Cropley, D. H., \& Cropley, A. J. (1999). Creativity and innovation in systems engineering (Doctoral dissertation, Systems Engineering Society of Australia).

Cropley, D. H., \& Cropley, A. J. (2000). Fostering creativity in engineering undergraduates. High ability studies, 11(2), 207-219.

Daly, S. R., Mosyjowski, E. A., \& Seifert, C. M. (2014). Teaching creativity in engineering courses. Journal of Engineering Education, 103(3), 417-449. doi:10.1002/jee.20048

De la Torre, S. (1991). Evaluación de la creatividad. Test de abreacción para evaluar la creatividad. TAEC.

Dewulf, S., \& Baillie, C. (1999). CASE: Creativity in Art, Science and Engineering: How to foster creativity. Great Britain Department for Education and Employment.

Elliott, M. (2001). The well-rounded IE: Breakthrough thinking. IE Solutions.

George, D., \& Mallery, M. (2003). SPSS for Windows step by step: a simple guide and reference. Boston: Allyn \& Bacon.

Gobert, J. D. (2005). The effects of different learning tasks on model-building in plate tectonics: Diagramming versus explaining. Journal of Geoscience Education, 53(4), 444-455.

Kazerounian, K., \& Foley, S. (2007). Barriers to creativity in engineering education: A study of instructors and students perceptions. Journal of Mechanical Design, 129(7), 761-768.

Kirkpatrick, E. A. (1907). A broader basis for psychology necessary. The Journal of Philosophy, Psychology and Scientific Methods, 4(20), 542-546.

Knoll, W. \& Hechinger, M. (2005). Maquetas de arquitectura, Técnicas y construcción. $6^{\text {a }}$ Ed. Barcelona: Ed. Gustavo Gili S.A. 
Lanca, M. (1998). Three-dimensional representations of contour maps. Contemporary educational psychology, 23(1), 22-41.

Lifante Gil, Y. (2011). Ingenieros Creativos. Valencia: Editorial Alfa Delta Digital.

Liu, Z., \& Schonwetter, D. J. (2004). Teaching creativity in engineering. International Journal of Engineering Education, 20(5), 801-808.

Project, Competences Tuning. (2016). Retrieved from http://www.unideusto.org/tuningeu/home.html

Saorín, J. L., De La Torre, J., Melián, D., Meier, C., \& Lifante,Y. (2015). Competencia creativa en estudios de Grado en Ingeniería. Artículo presentado al congreso al III Congreso sobre aprendizaje, innovación y competitividad. CINAIC. Madrid, Spain.

Saorín, J. L., Melián Diaz, D., Bonnet, A., Carbonell-Carrera, C., Meier, C., \& De la Torre, J. (2017). Makerspace teaching-learning environment to enhance creative competence in engineering students. Thinking Skills and Creativity. 23, 188-198. doi:10.1016/j.tsc.2017.01.004

Scott, G., Leritz, L. E., \& Mumford, M. D. (2004). The effectiveness of creativity training: A quantitative review. Creativity Research Journal, 16(4), 361-388.

Spanish Cabinet's Office. (2007). Royal Decree 1393/2007 from October 29th. State's Official Bulletin. Retrieved on 1 May 2013 from http://www. boe.es/buscar/pdf/2007/BOE-A-2007-18770-consolidado.pdf

Stavric, M., Sidanin, P., \& Tepavcevic, B. (2013). Architectural scale models in the digital age: design, representation and manufacturing. Basel: Birkhäuser.

Sternberg, R. J. (1999). Estilos de pensamiento. Paidos Iberica, Ediciones S. A..

Sternberg, R. J., \& Lubart, T. I. (1995). Defying the crowd: Cultivating creativity in a culture of conformity. Free Press.

Stouffer, W. B., Russell, J. S., \& Oliva, M. G. (2004, June). Making the strange familiar: Creativity and the future of engineering education. In Proceedings of the 2004 American Society for Engineering Education Annual Conference $\mathcal{E}$ Exposition (pp. 20-23).

Tulla, A., Busto, J. R., Gabilondo, A., Ruiz-Rivas, C., Laka, J. P., \& Roselló, G. (2004). White Paper Degree in Geography and Planning, 177-186. Madrid: National Agency for Quality Assessment and Accreditation (ANECA).

Weisberg, R. (1986). Creativity: Genius and other myths. WH Freeman/Times Books/Henry Holt \& Co.

Zappe, S. E., Reeves, P. M., Mena, I. B., \& Litzinger, T. A. (2015), A cross-sectional study of engineering students' creative self-concepts: An exploration of creative self-efficacy, personal identity, and expectations. Paper presented at 2015 ASEE Annual Conference E Exposition, Seattle, Washington. 10.18260/p.23373

Zappe, S., Mena, I., \& Litzinger, T. (2013, January). Creativity is not a purple dragon. In National Collegiate Inventors and Innovators Alliance. Proceedings of the... Annual Conference (p. 1). National Collegiate Inventors \& Innovators Alliance.

Zevi, B. (1997). Storia e controstoria dell'architettura in Italia. Newton \& Compton.

\section{http://www.ejmste.com}

